\title{
Confocal Laser Scanning Microscopic Analysis of the Depth of Dentin Caries-Like Lesions in Primary and Permanent Teeth
}

\author{
Fabíola Galbiatti de CARVALHO ${ }^{1}$ \\ Suzana Beatriz Portugal de FUCIO ${ }^{1}$ \\ Mario Alexandre Coelho SINHORETI ${ }^{1}$ \\ Lourenço CORRER-SOBRINHO ${ }^{1}$ \\ Regina Maria PUPPIN-RONTANI ${ }^{2}$
}

\author{
${ }^{1}$ Department of Dental Materials, Dental School of Piracicaba, State University of Campinas, Piracicaba, SP, Brazil \\ ${ }^{2}$ Department of Pediatric Dentistry, Dental School of Piracicaba, State University of Campinas, Piracicaba, SP, Brazil
}

\begin{abstract}
This study analyzed comparatively, by confocal laser scanning microscopy (CLSM), the depth of caries-like lesions produced by biological and chemical artificial models in permanent and primary dentin. Six primary molars and six premolars were used. The occlusal enamel was removed and a nail polish layer was applied on the specimens, except for a $4 \times 2 \mathrm{~mm}$ area on dentin surface. Half of specimens were immersed in acid gel for 14 days (chemical model) and the other half was immersed in BHI broth with $S$. mutans for 14 days (biological model). After development of artificial caries, the crowns were longitudinally sectioned on the center of the carious lesion. Three measurements of carious dentin depth were made in each specimen by CLSM. Measurements depths were compared between the caries models and between tooth types by one-way ANOVA and Tukey test $(\alpha=5 \%)$. For permanent teeth, the biological model showed significantly higher $(\mathrm{p}<0.05)$ caries depth values than the chemical model. For primary teeth, no statistically significant difference ( $p>0.05)$ was found between the caries models. The artificial caries model influenced caries depth only in permanent teeth. There was no difference in carious dentin depth between permanent and primary teeth, regardless of the artificial caries model.
\end{abstract}

Key Words: confocal laser scanning microscopy, caries, dentin, S. mutans.

\section{INTRODUCTION}

The evaluation of secondary caries inhibition by dental materials has increased in the last years due to the incorporation of fluoride and antibacterial components to restorative materials (1-4). In vitro studies produce artificial caries to simulate the cariogenic challenge and analyze the cariostatic effect of materials by mineral loss (3), microhardness (3), inhibition zone formation and depth of developed outer lesion $(1,2)$.

The artificial caries models found in the literature focus on physicochemical aspects of dental caries, namely static (acid gel or solutions) $(1,2)$ or dynamic ( $\mathrm{pH}$ regimens) $(4,5)$ chemical models, and can also use microorganisms as acid producers in cultures $(1,6)$, known as biological models. Different methodologies have been indicated to assess the depth of carious lesions produced in these models, such as microradiography (3), polarized light microscopy (3) and confocal laser scanning microscopy (CLSM) (2).

CLSM is able to identify tissue-emitting fluorescent signal and has been widely used to validate the extension and removal of carious dentin (7-11), which exhibits natural autofluorescence (AF) detectable by CLSM. The advantages of CLSM include a non-destructive examination and no neeed of specimen drying, which minimized the risk of technical artifacts (12). Carious dentin has a strongly increased AF compared to

Correspondence: Profa. Dra. Regina Maria Puppin-Rontani, Departamento de Odontologia Infantil, Faculdade de Odontologia de Piracicaba, UNICAMP, Avenida Limeira, 901, 13414-903 Piracicaba, SP, Brasil. Tel: +55-19-2106-5286. Fax: +55-19-2106-5218. email: rmpuppin@fop.unicamp.br 
its sound counterpart (7). Although it is assumed that AF is caused by mineral loss (11) and an interaction between modified matrix molecules and bacteria present in the infected dentin lesion $(8,13)$, its main cause remains unknown. Furthermore, the literature is controversial regarding AF in artificial carious lesion. While in some studies AF was verified only in lesions induced by bacteria $(8,13)$, another study visualized $\mathrm{AF}$ in lesions induced by carboxymethylcellulose gel (bacteria free) (11). Comparative studies of caries development have shown that caries progression is faster in the primary than in the permanent dentition $(14,15)$, but this difference was not studied by CLSM.

The aim of this study was to analyze comparatively by CLSM the depth of artificial carious dentin lesions produced by biological and chemical models in permanent and primary teeth. The tested hypothesis is that artificial carious dentin lesions have the same depth when produced by either biological or chemical models in both permanent and primary teeth.

\section{MATERIAL AND METHODS}

\section{Preparation of Dentin Specimens}

This study was performed under the protocol approved by the Research Ethics Committee of the Dental School of Piracicaba, University of Campinas, Brazil.

Intact extracted 1st primary molars and $1 \mathrm{st}$ premolars were selected. Teeth were stored in $0.1 \%$ thymol for 1 month and then stored in distilled water at $4^{\circ} \mathrm{C}$ until use. The occlusal enamel was sectioned perpendicular to tooth long axis with a water-cooled low-speed diamond saw (Isomet; Buehler Ltd., Lake Bluff, IL, USA) to expose the subjacent dentin. Dentin was wet ground flat with 180- and 400-grit silicon carbide paper until a uniform enamel-free dentin surface was obtained. The roots were sectioned $1 \mathrm{~mm}$ short of the cementoenamel junction and discarded. The pulp chamber was filled with composite resin. Specimens were painted with an acid-resistant nail polish (Colorama; CEILCom. Exp. Ind.Ltda., São Paulo, SP, Brazil), except for a $4 \times 2 \mathrm{~mm}$ area in the coronal dentin that would be further submitted to artificial caries development.

\section{Artificial Caries Development}

Two models of artificial caries development were used: biological (broth culture with Streptococcus mutans - UA159) and chemical (carboxymethylcellulose acid gel). Four groups $(n=6)$ were formed according to the caries development model and tooth type: I) primary artificial carious dentin and S. mutans; II) primary artificial carious dentin and carboxymethylcellulose acid gel; III) permanent artificial carious dentin and $S$. mutans; IV) permanent artificial carious dentin and acid carboxymethylcellulose gel.

Specimens from Groups I and III were fixed with orthodontic wire on the lids of glass vials containing $22 \mathrm{~mL}$ of sterile distilled water and immediately autoclaved at $121^{\circ} \mathrm{C}$ for $15 \mathrm{~min}$, and then transferred to another glass vial containing $22 \mathrm{~mL}$ of sterile brain-heart infusion (BHI) broth (Becton Dickinson and Company, Sparks, MD, USA) supplemented with yeast extract (Himedia Laboratories, PVTLtd., Mumbai, India), 0.5\% glucose (Synth; LabSynth, São Paulo, SP, Brazil), 1\% sucrose (Synth; LabSynth) and 2\% S. mutans (UA159) for development of the artificial carious lesions (6). The concentration of this bacterial suspension was determined by measuring absorption at $660 \mathrm{~nm}\left(\mathrm{~A}_{660}\right)(16)$. In order to adjust the number of viable bacteria to $A_{660}$, the number of colony-forming units per milliliter of bacterial suspension $(\mathrm{cfu} / \mathrm{mL})$ was determined with the use of standard spreading techniques at carious optical densities (16). Inoculation occurred only in the first day of the experiment, but the broth was renewed every 48 $\mathrm{h}$ during 14 days (6). Contamination of the broth was checked very day using Gram staining.

Specimens from Groups II and IV were fixed with orthodontic wire on the lids of glass vials containing $22 \mathrm{~mL}$ of $6 \%$ carboxymethylcellulose acid gel (Proderma Pharmacy, Piracicaba, SP, Brazil) at $\mathrm{pH} 5.0$ and $37^{\circ} \mathrm{C}$. The gel contained $0.1 \mathrm{M}$ lactic acid titrated to $\mathrm{pH} 5.0$ with a concentrated $\mathrm{KOH}$ solution (11). The specimens remained in the gel for 14 days without renewal (1).

After artificial caries development, specimens were washed with distilled water and sectioned mesiodistally on the center of the carious lesion with a water-cooled low-speed diamond saw (Isomet; Buehler Ltd.) providing two halves.

\section{Confocal Laser Scanning Microscopy}

Both halves of each carious dentin specimen were stored in water and kept humid throughout the investigation. Measurements were carried out with a 
confocal laser scanning microscope (LSM-510 META; Carl Zeiss, Jena, Germany) using 4x/0.13 objective and an Argon gas laser source with excitation band at 488 $\mathrm{nm}$ wavelength and the $505 \mathrm{~nm}$ long pass filter was used to detect the AF. Higher magnification of caries central area was also visualized using 20x/0.4 (corr) objective to analyze carious dentin morphology. Histotomographic images (parallel to the surfaces) were recorded within the specimens. Standard settings for contrast, brightness and laser power were used for all images.

Three measurements of carious dentin depth were performed in each specimen at 3 equidistant points $(500 \mu \mathrm{m})$ of the lesion border. An average depth for each specimen was calculated from the individual values based on fluorescence difference between demineralized and sound dentin (7).

\section{Statistical Analysis}

One-way ANOVA and Tukey post-hoc test were used to compare the depth carious dentin measurements between biologic and chemical artificial caries development model, and between primary and permanent teeth. Statistical significance level was set at $\alpha=0.05$.

\section{RESULTS}

The results are presented in Table 1. For permanent dentin, there was statistically significant difference ( $p=0.01)$ on caries depth measurements when the biological and chemical models were compared, while for primary dentin, no statistically significant difference $(p=0.28)$ was found between the models. There was no

Table1. Dentin caries depth measured by CLSM in lesions produced in primary and permanent teeth using different artificial caries development models.

\begin{tabular}{lcc}
\hline & Primary teeth & Permanent teeth \\
\hline Biological model & $233.4(20.79) \mathrm{A}, \mathrm{a}$ & $259.39(96.25) \mathrm{A}, \mathrm{a}$ \\
Chemical model & $204.4(92.95) \mathrm{A}, \mathrm{a}$ & $138.90(6.05) \mathrm{A}, \mathrm{b}$ \\
\hline
\end{tabular}

Mean (SD) expressed in mm. Same uppercase letters indicate no statistically significant difference between tooth types (columns) (ANOVA and Tukey test; $p>0.05$ ). Same lowercase letters indicate no statistically significant difference between caries model (rows) (ANOVA and Tukey test; $\mathrm{p}>0.05$ ). significant difference between primary and permanent dentin caries depth measurements when submitted to either the biological $(p=0.54)$ or the chemical $(p=0.11)$ model. CLSM images of permanent dentin showed that the biological model (Fig. 1A) produced deeper lesions than the chemical model (Fig. 1B). In addition, the biological model produced a carious tissue with more demineralization and well-defined tubules (Fig. 2A), while the chemical model produced a more dense and compact structure, without well-defined dentina tubules (Fig. 2B). Regarding the primary dentin, the CLSM images showed no difference between the caries models (Fig. 3A and B), and dentin tubules were very evident in both methods (Fig. 4A and B).

\section{DISCUSSION}

The dentin has a property named AF, which results from the presence of chromophores in dentin (11). News devices have been developed to diagnose and remove caries using fluorescent procedures, such as Diagnodent (17) and fluorescence-aided caries excavation (FACE) (10). It has been demonstrated that the use of optical fibers coupled to a low-speed handpiece to generate light and excite the chromophores allowed the operator identifying and removing carious dentin more accurately than by visual and tactile criteria (10). Thus, under clinical conditions, the analysis of carious dentin AF can be a helpful auxiliary method for the identification and safe removal of carious tissue.

Although some studies $(9,13)$ have suggested that the AF of caries-like lesions would be due exclusively to the presence of bacteria in the infected dentin because of the bacteria/dentin matrix interaction, the results of the present study indicate that dentin mineral loss could also be associated with an increased AF, even in bacteria-free conditions. Similar results have been reported elsewhere $(11,18)$.

The tested hypothesis that artificial carious dentin lesions produced by either biological or chemical models in both permanent and primary teeth would have the same depth was rejected. There was difference between the models for permanent dentin. CLSM images showed that the biological model was more aggressive, developing deeper lesions and causing a higher demineralization in dentin structure than the chemical model (Figs. 1A and 4A), which produced thinner lesions (Fig. 1B). The low pH of artificial caries 
models produces a mineral loss from teeth to the surrounding environmental medium (gel or broth). In the biological model, the constant change of broth (every $48 \mathrm{~h}$ ) might have promoted an unsaturated environment of minerals, leading to a continuous demineralization of specimens. In addition, sucrose and glucose supplied in the broth represents a nutrient source for acid production by $S$. mutans, keeping the $\mathrm{pH}$ around 4.0 (19). Unlike this conditions, the specimens in gel were maintained at $\mathrm{pH} 5.0$ for 14 days without renewal.

Regarding primary dentin, the higher magnification of caries-like images verified similar characteristics about depth and morphology in both models (Fig. 4A and B). Since primary teeth shows a reduced degree of mineralization compared to permanent teeth (20), their
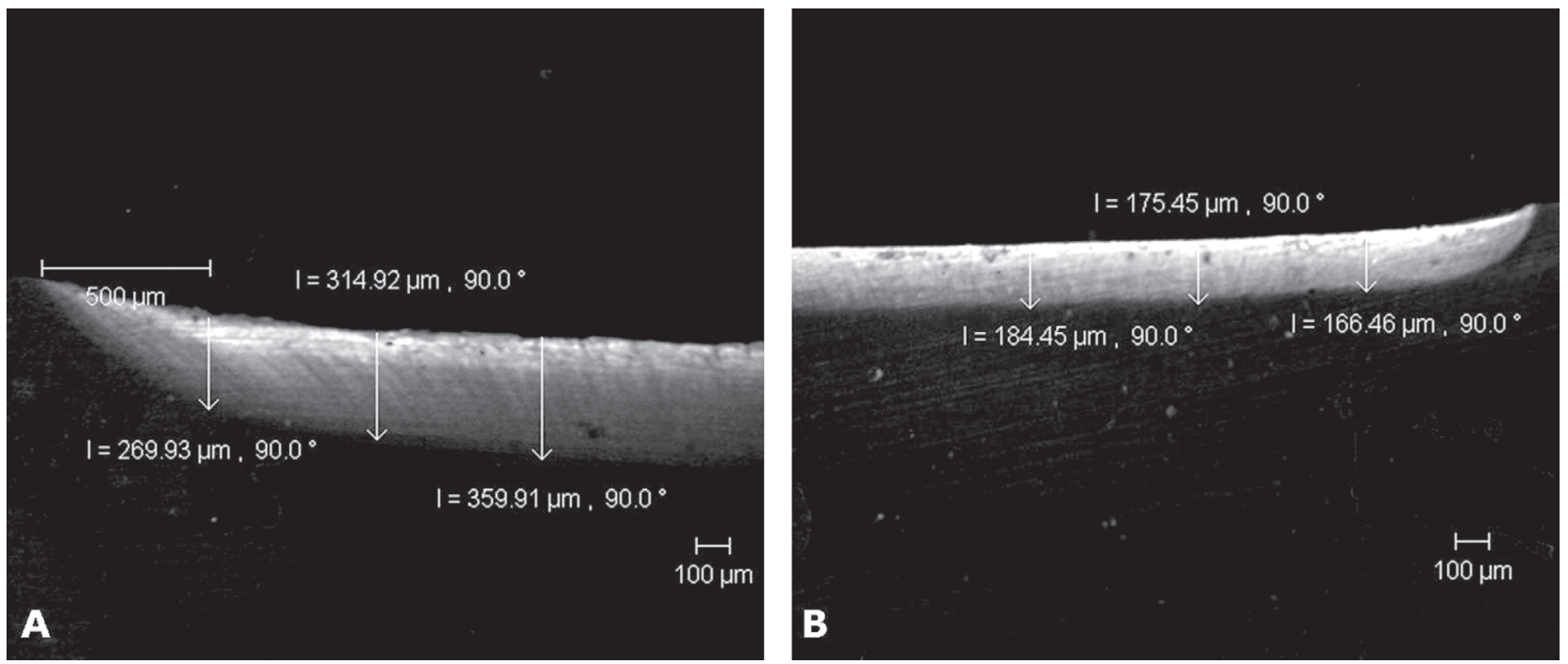

Figure 1. Analysis of artificial caries depth in permanent teeth produced by biological (A) and chemical (B) models by CLSM (4x/ 0.13 corr).
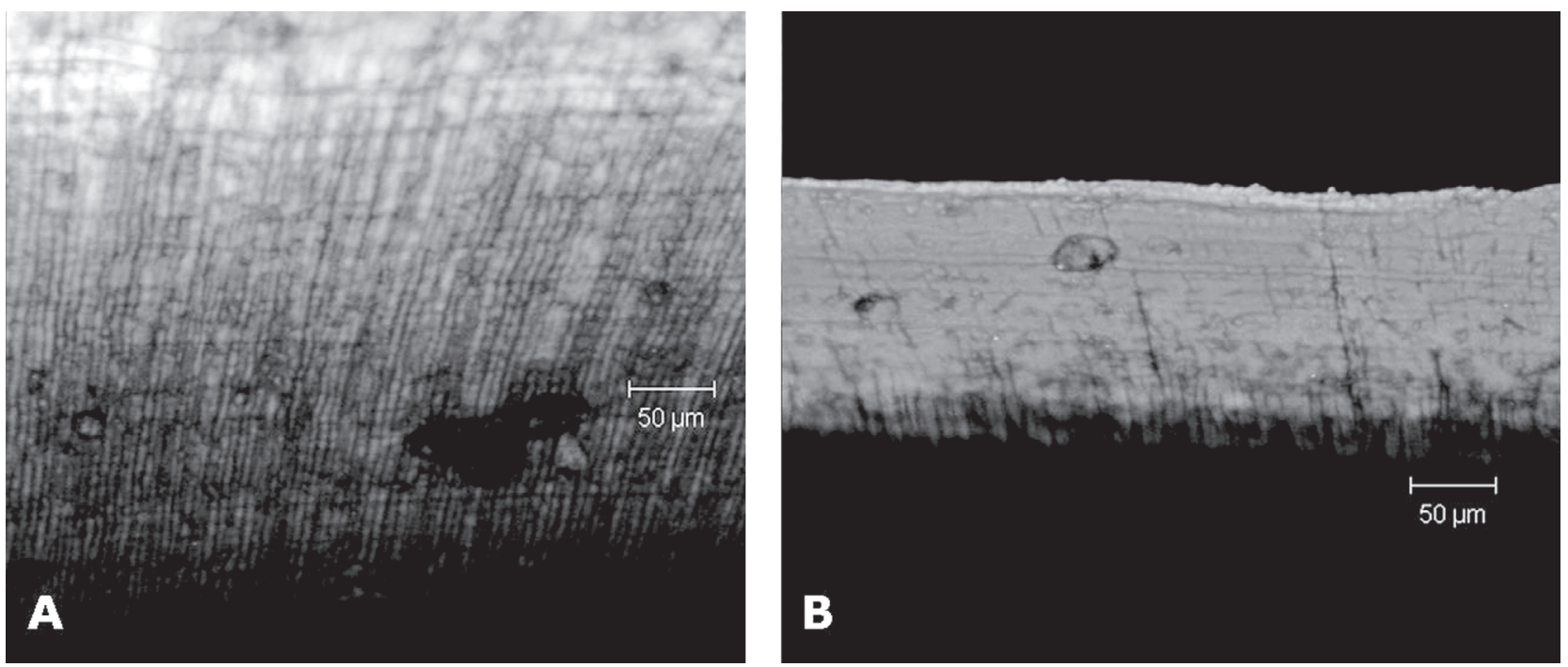

Figure 2. Greater magnification of caries-like images in permanent teeth produced by biological (A) and chemical (B) models in CLSM (20x/0.4 corr). 
resistance to cariogenic challenge is reduced and both models were aggressive to primary dentin. The chemical model produced caries depth comparable to those produced by the biological model and no statistical difference was found between the artificial caries models.

Caries dentin was excavated with curettes for tactile exam in both types of teeth. The carious tissue produced with biological model presented a structure more similar to that of natural caries. It was softer and looser than the tissue produced by the chemical model, resembling the infected-caries dentin. The chemical carious tissue presented a rubbery and dense structure, as observed by CLSM. However, other studies are necessary to evaluate the molecular, physical and mechanical properties of artificial carious dentin in order to define which model is more appropriate. The
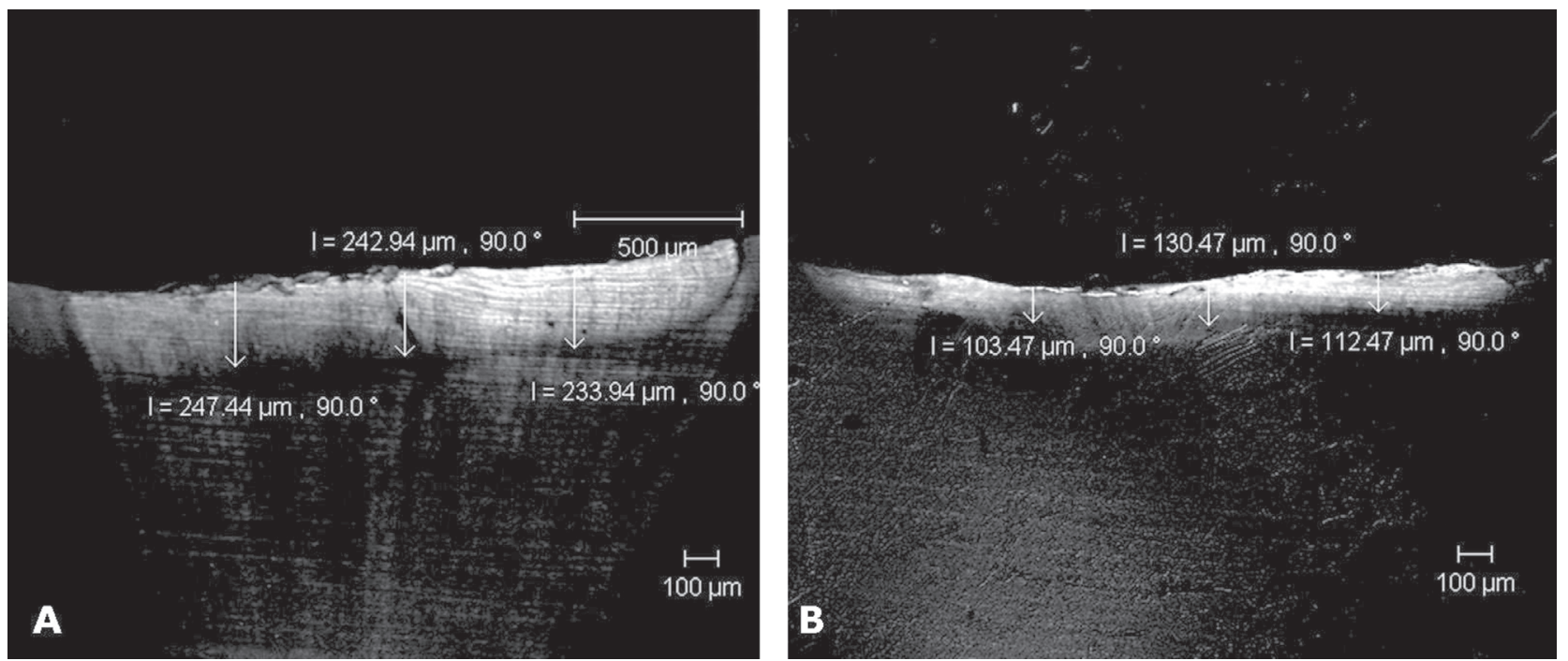

Figure 3. Analysis of artificial caries depth in primary teeth produced by biological (A) and chemical (B) models by CLSM (4x/0.13 corr).
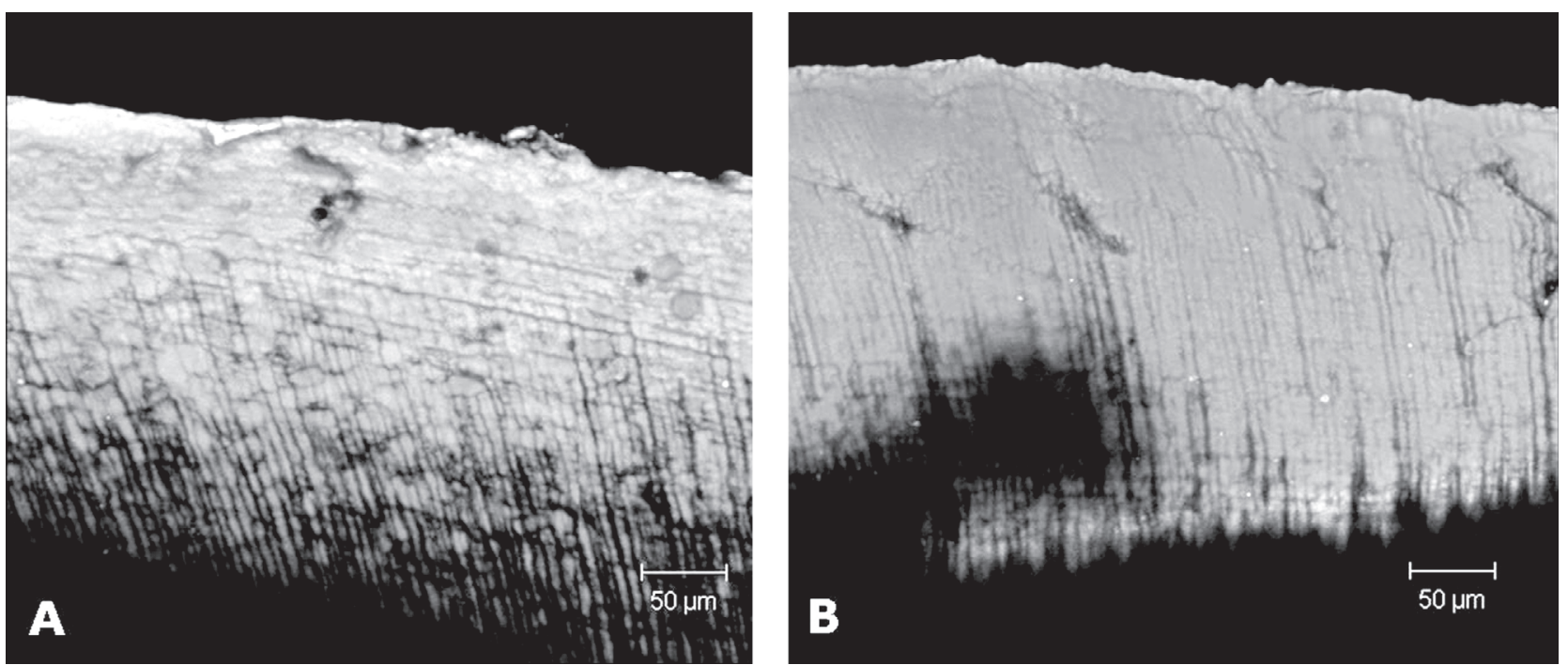

Figure 4. Greater magnification of caries-like images in primary teeth produced by biological (A) and chemical (B) models in CLSM (20x/0.4 corr). 
findings of this CLSM study showed that for permanent teeth, there was significant difference on caries depth measurements comparing the biological and chemical models, whereas for primary dentin, no significant difference was found between the models. Furthermore, there was no significant difference between primary and permanent teeth comparing carious dentin depth by CLSM analysis, regardless of the artificial caries model.

\section{RESUMO}

O objetivo deste estudo foi comparar a profundidade de cárie produzida em dentina permanente e decídua por modelos biológico e químico de produção artificial de cárie utilizando o microscópio confocal de varredura a laser (CLSM, na sigla em Inglês). Seis molares decíduos e seis pré-molares foram usados. O esmalte oclusal foi removido expondo a dentina subjacente. A seguir, um verniz de unha foi aplicado em toda a amostra, exceto em uma área de $4 \times 2 \mathrm{~mm}$ na superfície dentinária. Metade das amostras foi imersa em gel ácido por 14 dias (modelo químico) e a outra metade imersa em BHI com S. mutans por 14 dias (modelo biológico). Após o desenvolvimento da cárie artificial, as coroas foram seccionadas longitudinalmente no centro da lesão de cárie. Três medidas da profundidade de cárie produzida foram realizadas ao longo de cada espécime e analisadas em CLSM. As medidas da profundidade de cárie entre os modelos e entre os tipos de dentes foram analisadas pelo teste de ANOVA a um critério e teste de Tukey $(\mathrm{p}<0,05)$. Para os dentes permanentes, o modelo biológico mostrou maiores valores de profundidade de cárie quando comparado ao modelo químico. Entretanto, para os dentes decíduos não houve diferença estatisticamente significante na profundidade de cárie entre os modelos. Desta forma, o modelo de produção de cárie artificial influenciou a profundidade de cárie apenas para os dentes permanentes, não existindo diferença na profundidade de cárie entre dentes decíduos e permanentes, independente do modelo de cárie utilizado.

\section{ACKNOWLEDGEMENTS}

The authors would like to thank Mr. Alexsander Seixas de Souza and Dr. Toshie Kawano of the Butantan Institute for their technical support for CLSM. This study was supported by FAPESP (Protocol \# 05/57268-9).

\section{REFERENCES}

1. Kuramoto A, Imazato S, Walls AWG, Ebisu S. Inhibition of root caries progression by an antibacterial adhesive. J Dent Res 2005;84:89-93.

2. Okuda M, Pereira PNR, Nikaido T, Tagami J. Evaluation of in vitro secondary caries using confocal laser scanning microscope and X-ray analytical microscope. Am J Dent 2003;16:191-196.

3. Savarino L, Breschi L, Tedaldi M, Ciapetti G, Tarabusi C,
Greco $\mathrm{M}$ et al.. Ability of restorative and fluoride releasing materials to prevent marginal dentine demineralization. Biomaterials 2004;25:1011-1017.

4. Tsuchiya S, Nikaido T, Sonoda H, Foxton RM, Tagami J. Ultrastructure of dentin-adhesive interface after acid-base challenge. J Adhes Dent 2004;6:183-190.

5. Rodrigues JA, Marchi GM, Serra MC, Hara AT. Visual evaluation of in vitro cariostatic effect of restorative materials associated with dentifrices. Braz Dent J 2005;16:112-118.

6. Lima LM, Motisuki C, Spolidorio DMP, Santos-Pinto L. In vitro evaluation of probiotics microorganism adhesion to an artificial caries model. Eur J Clin Nutrit 2005;59:884-886.

7. Banerjee A, Boyde A. Autofluorescence and mineral content of carious dentine: scanning optical and backscattered electron microscopic studies. Caries Res 1998;32:219-226.

8. Banerjee A, Kidd EAM, Watson TF. In vitro validation of carious dentin removed using different excavation criteria. Am J Dent 2003;16:228-230.

9. Banerjee A, Sherriff M, Kidd EAM, Watson TF. A confocal microscopy study relating the autofluorescence of carious dentine to its microhardness. Br Dent J 1999;187:206-210.

10. Lennon AM. Fluorescence-aided caries excavation (FACE) compared to conventional method. Oper Dent 2003;28:341345 .

11. van der Veen MH, ten Bosch JJ. The influence of mineral loss on the auto-fluorescent behaviour of in vitro demineralized dentine. Caries Res 1996;30:93-99.

12. Pioch T, Stotz S, Staehle HJ, Duschner H. Applications of confocal laser scanning microscopy to dental bonding. Adv Dent Res 1997;11:453-461.

13. Banerjee A, Gilmour A, Kidd E, Watson T. Relationship between $S$. mutans and the autofluorescence of carious dentin. Am J Dent 2004;17:233-236.

14. Shwartz M, Grondahl HG, Pliskin JS, Boffa J. A longitudinal analysis from bite-wing radiographs of the rate of progression of approximal carious lesions through human dental enamel. Arch Oral Biol 1984;29:529-536.

15. Sonju CAB, Ogaard B, Duschner H, Ruben J, Arends J, Sonju T. Caries development in fluoridated and non-fluoridated deciduous and permanent enamel in situ examined by microradiography and confocal laser scanning microscopy. Adv Dent Res 1997;11:442-447.

16. Boeckh C, Schumacher E, Podbielski A, Haller B. Antibacterial activity of restorative dental biomaterials in vitro. Caries Res 2002;36:101-107.

17. Olmez A, Tuna D, Oznurhan F. Clinical evaluation of diagnodent in detection of occlusal caries in children. J Clin Pediatr Dent 2006;30:287-291.

18. van der Veen $\mathrm{MH}$, ten Bosch JJ. Autofluorescence of bulk sound and in vitro demineralized human root dentin. Eur $\mathrm{J}$ Oral Sci 1995;103:375-381.

19. Hashizume LN, Shinada K, Kawaguchi Y, Yamashita Y. Sequence of ultrastructural changes of enamel crystals and Streptococcus mutans biofilm in early enamel caries in vitro. $\mathrm{J}$ Med Dent Sci 2002;49:67-75.

20. Angker L, Swain MV, Kilpatrick N. Micro-mechanical characterization of the properties of primary tooth dentine. J Dent 2003;31:261-267. 